This is a so-called personal version (authors' manuscript as accepted for publishing after the review process but prior to final layout and copyediting) of the article:

Mainela, T., Puhakka, V. and Servais, P. (2014), The Concept of International Opportunity in International Entrepreneurship: A Review and a Research Agenda. International Journal of

Management Reviews, 16: 105-129. doi: 10.1111/ijmr.12011.

Researchers are kindly asked to use the official publication in references.

\title{
The Concept of International Business Opportunity in Entrepreneurial Internationalization: A Review and a Research Agenda
}

\begin{abstract}
The recent definitions of international entrepreneurship have emphasized international business opportunities and behaviors focused on them as critical in entrepreneurial internationalization. International business opportunities, however, are often depicted in rather abstract and unspecified ways and the research suffers from narrow theoretical articulations and weak conceptual foundations in relation to the concept of opportunity. To address these issues, we draw from entrepreneurship research on opportunities alternative conceptualizations and their features as a basis for in-depth research on international business opportunities in entrepreneurial internationalization. To further articulate a future research agenda, we assess the state of the IE field by content-analyzing entrepreneurial internationalization articles, which incorporate the concept of opportunity, published between 1989 and 2010. We find that, although the entrepreneurial internationalization research has investigated many relevant elements, it is rather limited in articulation of the conceptual features of international business opportunities and behaviors focused on them. Building on these observations, we propose a definition of an international business opportunity and concrete strategies and research questions to advance entrepreneurial internationalization research focused on international business opportunities.
\end{abstract}

Keywords International entrepreneurship, international business opportunity, internationalization, arbitrage, innovation

\section{Introduction}

Over the last two decades international entrepreneurship (IE) research has increasingly moved on from its early emphasis on international new ventures towards studying a wider variety of international entrepreneurial behaviors. In addition to examining ventures "... that, from inception, seek to derive significant competitive advantage from the use of resources from and the sale of outputs in multiple countries" (Oviatt and McDougall 1994, p. 49), the 
field is defined to focus on "the discovery, enactment, evaluation, and exploitation of opportunities - across national borders - to create future goods and services" (Oviatt and McDougall 2005, p. 540). By definition, IE is a cross-disciplinary research field that combines international business and entrepreneurship (McDougall and Oviatt 2000). Greater cross-fertilization of entrepreneurship and international business research has, however, repeatedly been called for and the need for multi-disciplinary, balanced theoretical bases has been emphasized (Coviello and Jones 2004; Jones and Coviello 2005; Madsen and Servais 1997). IE research has been mostly about types of international ventures and internationalization of firms but much less about entrepreneurship (see Jones et al. 2011). A great variety of international firms, such as instant exporters, born regionals, born internationals and born globals has been observed (e.g. Moen and Servais 2002) and the timing, degree and speed of the internationalization of firms has attracted research interest (e.g. Acedo and Jones 2007; Kiss and Danis 2008). Understanding of the entrepreneurial behaviors involved in IE, however, necessitates looking for further conceptual building blocks for research.

International business opportunity (IBO) has grown in importance as a concept of IE research alongside the development of its root theories, particularly internationalization process and entrepreneurial opportunity theories. In recent decades, the research on internationalization of firms has moved from analysis of internal experience and gradual learning about international markets and operations (e.g. Bilkey and Tesar 1977; Cavusgil 1980; Johanson and Vahlne 1977) towards analyses of international opportunity development in relationship networks (Johanson and Vahlne 2006, 2009). Entrepreneurial innovation and opportunity identification have been depicted also as the core of MNEs (Casson et al. 2009; Godley and Casson 2007). For about a decade, as the key functions of entrepreneurship have been seen the entrepreneurial opportunity discovery and exploitation (Eckhardt and Shane 
2003; Shane and Venkataraman 2000; Short et al. 2010). Opportunity has been advocated as the concept best capturing entrepreneurship as a research field (Murphy 2011). On this basis, we suggest the concept of international business opportunity to hold a particular promise in developing the cross-disciplinary IE research further.

The research often depicts the IBO as a rather abstract phenomenon whose very features are difficult to capture. Therefore, IE research on IBOs encounters specific conceptual challenges. The extant research, however, seems to suffer from rather narrow theoretical articulations and weak conceptual foundations. We see acknowledging the complexity of the concept and the variety of approaches used to study it as important for the further development of IE research on IBOs. The entrepreneurship research around the nature of opportunities and opportunity-related behaviors (e.g. Alvarez and Barney 2007; Sarasvathy et al. 2003) has produced interesting debates to build on. We believe that building on this research is a prerequisite for more in-depth understanding of IBOs and opportunity focused behaviors in entrepreneurial internationalization.

To help address the conceptual concerns and develop IE research in accordance with the opportunity focused definition of the field, we develop a research agenda for the systematic study of IBOs in IE. The study facilitates the development of IE research on IBOs by analysis of how opportunities are conceptualized in the entrepreneurial opportunity research, in general, and how they are depicted and what is known about them in the IE field of research, in particular. Within the IE field, the review is about entrepreneurial internationalization and does not cover cross-country comparisons of entrepreneurship (cf. Jones et al. 2011). The aim of the study is to strengthen the conceptual foundations of IBO focused IE research through reflecting our current knowledge on IBOs in entrepreneurial internationalization upon the research on entrepreneurial opportunities.

To augment the contribution of IE research on IBOs, we present a research agenda for 
study of IBOs in entrepreneurial internationalization. We develop the agenda in three steps. First, we show how opportunities have become a shared interest of internationalization and entrepreneurship researchers. Second, we build on extant work on entrepreneurial opportunities to highlight various conceptualizations of opportunities. By doing so, we anchor our research agenda in the conceptual foundations of entrepreneurial opportunity research. Third, to better identify avenues for future IE research, we assess the manner and extent with which entrepreneurial internationalization research leverages in terms of conceptualizing and uncovering the IBOs. Moreover, through content analysis we depict the current state of knowledge on IBOs in entrepreneurial internationalization. By analyzing 70 articles incorporating explicitly opportunities into their studies over the period 1989-2010, we show that for all its achievements, extant research on entrepreneurial internationalization has yet to leverage the full potential of the IBO focus.

We build on these observations to formalize our research agenda. We suggest a definition of an IBO and propose a series of research questions and strategies that illustrate how one can address IBOs in entrepreneurial internationalization in more in-depth ways. These should assist in overcoming some of the current challenges and conceptual deficits in IBO focused IE research.

\section{Conceptual foundations of research on opportunities in IE}

IE as a research field has particularly evolved from the Oviatt and McDougall's (1994) article on international new venture theory (Autio 2005; Zahra 2005). McDougall (1989) had introduced the entrepreneurship angle, but the early research was dominated by the international business viewpoint, which emphasized the time lag (or rapidity) between the establishment of a new firm and its first international market entry. The research put most 
effort in to defining the antecedents and the necessary and sufficient conditions for the emergence of international new ventures or born globals (e.g. Jolly et al. 1992; Rennie 1993). The phenomenon was seen primarily related to developments in markets, technologies and the capabilities of people. Since the objects of research were young firms, a greater crossfertilization with entrepreneurship research was soon called for (e.g. Madsen and Servais 1997). McDougall and Oviatt (2000, p. 903), then, defined IE as "the innovative, proactive and risk-seeking behaviors across borders" and later emphasized behaviors on "opportunities - across national borders" (Oviatt and McDougall 2005, p. 540). Although the early research primarily contested traditional process models of international business and MNC emergence, the notion of 'opportunity' emphasizes the entrepreneurship dimension.

We believe that in study of IBOs we should build on the strong tradition of entrepreneurship research in studying entrepreneurial opportunities and opportunity-focused behaviors. However, the IE research faces an additional challenge of featuring the internationality of the opportunity through its relevant aspects. The appreciation of the crossborder nature of the opportunity is the specialty of international business research. Therefore, cross-fertilization of the theoretical roots of IE is necessary for in-depth research on IBOs. We start with grounding the analysis of IBOs in the developments in the internationalization process and entrepreneurship research.

\section{Opportunities in the internationalization process and entrepreneurship research}

The internationalization process theory, along with the process models of the 1970s (e.g. Bilkey and Tesar 1977; Johanson and Vahlne 1977), was the dominant international business paradigm in the rise of IE (Autio 2005). Essentially, the process models contend that firms tend to become international in an incremental manner - which may be due to lack of 
knowledge of foreign market risks and opportunities, high levels of perceived uncertainty, or other similar factors. One part of the research sees internationalization processes as involving time consuming organizational learning processes, while another analyzes the process as an innovative course of action, and therefore, a question of adoption of new ways of doing business (Andersen 1993).

One point noted early on (Welch and Wiedersheim-Paul 1980; Wiedersheim-Paul et al. 1978), was that interaction with counterparts who do international business, permits managers with an international outlook and mental map, to obtain information on export market opportunities and move towards their exploitation. Research at the end of the 1980s led to further theorizing on international networks (e.g. Johanson and Mattsson 1988) and also saw the networks connected to the internationalization process of the firms (Johanson and Vahlne 1990). Since then networks have attracted significant research efforts (see e.g. Coviello 2006; Coviello and Munro 1995; Johanson and Vahlne 2003). The latest internationalization process model (Johanson and Vahlne 2009) defines opportunities as the subset of knowledge that is the single most important driver of internationalization. The knowledge of an IBO is accessed and developed through relationships.

The origins of modern entrepreneurship research, the other root, are in the economic thought of Schumpeter (1934) and his fellows in the Austrian school (e.g. Hayek 1948; Kirzner 1973). The basis of opportunity-centered research could already be discerned in the research from the 1980s on behaviors for creation of new businesses, new market entries and launches of new ventures in any organizational context (Stevenson and Gumpert 1985; Stevenson and Jarillo 1986, 1990 ). Together with Gartner's (1988) seminal article, the ideas by Stevenson and his colleagues moved entrepreneurship research from searching for the qualities of entrepreneurs, of small firms or of entrepreneurial communities to studying entrepreneurship as behavior (e.g. Lumpkin and Dess 1996; Zahra et al. 1999). Accordingly, 
entrepreneurial opportunity research is interested in "how, by whom, and with what effects opportunities to create future goods and services are discovered, evaluated, and exploited" (Shane and Venkataraman 2000, p. 218) and in the actions creating new business regardless of the organizational context (Davidsson 2004; Shane 2003).

The entrepreneurial opportunity-centered behaviors have been defined in many ways (see Short et al. 2010). One approach sees opportunity discovery as a rational process of organizing information in order to construct a strategic business concept to create new economic value (e.g. Ireland et al. 2003; Newey and Zahra 2009). A related approach considers the discovery of opportunity to be one of the activities through which a new venture is organized (e.g. Davidsson et al. 2006; Santos and Eisenhardt 2009). Another approach argues that opportunity discovery is about gathering and interpreting information in order to find information gaps related to markets, technologies or needs (e.g. Cohen and Winn 2007; Ozgen and Baron 2007). Still another stresses the rational and creative behaviors combined in the opportunity discovery (e.g. Ardichvili et al. 2003; Mitchell and Shepherd 2010). The final one views the discovery of opportunity as a social and culturally embedded discourse developing opportunities through dialogue (e.g. Fletcher 2007; Rindova et al. 2009). One can either distinguish the views on the basis of their emphasis on new ventures creating new economic value versus economic activity removing market inefficiencies; or on the basis of rational decision making versus socially embedded acting on opportunities.

Despite the significant amount of research on opportunity related behaviors, defining the opportunity as the object of those behaviors is not a straightforward task; research has advocated several conceptualizations, as discussed below. According to our interpretation, research suggests differentiating innovation and arbitrage opportunities and opportunity discovery and opportunity creation. 
Conceptualizations of opportunities

One of the most common definitions of entrepreneurial opportunities is that offered by Eckhardt and Shane (2003, p. 336) as "situations in which new goods, services, raw materials, markets and organizing methods can be introduced through the formation of new means, ends, or means-ends relationships". An opportunity is here a situation in which new combinations producing economic value can be formed but the elements used fundamentally exist already. Different types of opportunities exist because opportunities occur as a result of changes in different parts of the value chain. A different definition is presented by Sarasvathy et al. (2003, p. 79) who propose an opportunity is "a set of ideas, beliefs and actions that enable the creation of future goods and services in the absence of current markets for them". Hence opportunity arises from perceptions and behaviors combined in an attempt to create new economic artifacts.

The conceptualizations of opportunity do generally share the view that it revolves around value creation and competitive imperfections (Alvarez and Barney 2007, 2010; Ardichvili et al. 2003). Our characterization of opportunities builds on two primary claims about the nature of entrepreneurship. The first is that entrepreneurship is about generation of new economic activity. Seminal work analyzing this activity has been presented by Joseph Schumpeter and Israel Kirzner. The former focuses on innovation and the second on arbitrage as the basis for new economic activity. We rely on these views to discuss what constitutes an opportunity. The second core claim is that entrepreneurship is behavior. The differentiation between opportunity discovery and opportunity creation tackles the two main types of behaviors that have been debated in entrepreneurship literature. It answers the question of how opportunities are generated through entrepreneurship.

Innovation opportunities move markets towards disequilibrium through creative 
destruction, at which point entrepreneurs innovate new solutions of greater value to the markets than the existing options (Schumpeter 1934, see also Autio 2005; Zahra 2005). The opportunity arises from the entrepreneurial creativity, which, in turn, builds on the dissatisfaction of the entrepreneurs with the current options (McMullen and Shepherd 2006). These are situations where economic invention is needed before business can be created because either supply or demand is absent (Ardichvili et al. 2003; Eckhardt and Shane 2003; Sarasvathy et al. 2003). The development of innovation opportunities is primarily driven by the motivation, attitude and risk propensity of the entrepreneurs (McMullen and Shepherd 2006). It focuses on an entrepreneurial idea of a new venture that brings new economic value (Anokhin et al. 2011; Davidsson 2004; Eckhardt and Shane 2003; Shane 2000). Internationalization comes to the fore based on the need for innovative cross-border resource combinations (Autio 2005).

Markets in a state of disequilibrium present arbitrage opportunities - the entrepreneur addressing the disparity between supply and demand then moves the market towards a state of equilibrium (Anokhin et al. 2011; Autio 2005; Kirzner 1973). Both supply and demand exist but an entrepreneur needs to recognize the opportunity to put them together (Ardichvili et al. 2003; Eckhardt and Shane 2003; Sarasvathy et al. 2003). Thus, arbitrage opportunities arise from the failure of market mechanism resulting in market inefficiencies (Anokhin et al. 2011). Arbitrage opportunities present themselves to alert individuals who perceive the market inefficiencies because of their skills in acquiring, interpreting and using disparate sources of market information (Anokhin et al. 2011; Eckhardt and Shane 2003; Kirzner 1973, 1997). Entrepreneurship, therefore, is defined by differences in knowledge (McMullen and Shepherd 2006). The arbitrage opportunity is not about contributing novelty value to the markets as such, but covers the way a firm is going to operate in the foreign market in order to meet an unsatisfied need. 
The opportunity discovery arises from exogenous shocks, for example industry or market changes beyond the influence of entrepreneurial action and they exist regardless of whether people are aware of their existence (Alvarez and Barney 2007). In our interpretation, opportunities through new means, ends or means-end frameworks (Eckhardt and Shane 2003) are generated through opportunity discovery. They are about the possibility of putting resources to better use or discovering new solutions or new needs, and the most suitable options for their realization (Sarasvathy et al. 2003). There will be either a solution or a need as a starting point. Opportunity discovery is realized through active, although not necessarily purposeful, search behavior. The behavior focuses on to discover economic opportunities arising from exogenous changes, like for example technological inventions (Shane 2000). Thus, entrepreneurs might discover a variety of opportunities based on the same exogenous change. The opportunities are characterized as complex entities whose discovery is a process in which new features are added to the opportunity content as an original work by an entrepreneur (Ardichvili et al. 2003). Exploiting the opportunity entails risk, but risk can be estimated and allow for rational decision making (Alvarez and Barney 2007). The emphasis in opportunity discovery is on resource allocation and use in the initiation of the business. The internationalization process research has traditionally emphasized exogenously-born opportunities that exist in foreign markets to be recognized and exploited by firms (Andersen 1993; Autio 2005).

Opportunity creation is actualized through enactment of human imagination and social interaction as a continuous process (Alvarez and Barney 2007, 2010; Chiles et al. 2007). The opportunity appears as a flexible activity of creating meaning, sense-making and sense-giving in an ambiguous social context (Cornelissen and Clarke 2010; Wood and McKinley 2010, cf. Rasmussen et al. 2001). This view is evident in the definition of opportunity by Sarasvathy et al. (2003). Instead of being actively searched out, the opportunities are endogenously formed 
in the unfolding of the everyday entrepreneurial practice and interactions between various actors (De Clercq and Voronov 2009; Sarasvathy et al. 2003; Steyaert 2007; Van de Ven and Engleman 2004). Opportunity creation is connected with true uncertainty where neither supply nor demand exists and the future is unknowable (Sarasvathy et al. 2003). Entrepreneurs engage in a learning process marked by a gradual investment of resources and convincing others to change vague and unformed aspirations into tangible products, services or new markets (Alvarez and Barney 2007). In terms of internationalization, the innovation models depict internationalization as an endogenously created opportunity for the firm (Andersen 1993, cf. Autio 2005).

Our view is that innovation and arbitrage opportunities and opportunity discovery and opportunity creation can be seen as different conceptualizations of entrepreneurial opportunities that are based on different streams of entrepreneurship research and have differentiating characteristics (see Table 1). Acknowledging those is important for consistent conceptualizations and concept use when theorizing about opportunities. However, we do not see them as exclusive and therefore they can be approached also as elements in conceptualizing opportunities.

Insert Table 1 about here.

The previous research argues in particular about opportunity discovery and opportunity creation seeing them both as contradictory and complementary views. Alvarez and Barney (2010) see opportunity discovery and opportunity creation as epistemologically different views that can hardly co-exist. Chiasson and Saunders (2005), in turn, see discovery and creation as complementary approaches and Vaghely and Julien (2010) propose an integrative framework which connects opportunity discovery and opportunity creation in entrepreneurial 
behavior. Edelman and Yli-Renko (2010) show empirically that discovery and creation are intertwined in entrepreneurial action. The studies combining discovery and creation focus on the ways of behaving of the entrepreneurs and do not make ontological or epistemological differentiation of concepts. We see all ontological and epistemological stances on opportunities as legitimate but, in line with Alvarez and Barney (2010), see it as important to be explicit about them in the conceptualization of the IBO.

In an attempt to create a solid basis for our review as well as for future research on IBOs, we examined the concept of opportunity in internationalization and entrepreneurship research and particularly analyzed the research on entrepreneurial opportunities. The above conceptualizations of opportunities form a basis of reflection in the following review. However, they are not used as a strict classification tool to be able to appreciate the specificities of the reviewed literature.

\section{Methodology of the review}

To identify avenues for opportunity-focused entrepreneurial internationalization research, along with the above research on opportunities, we content analyze articles published 19892010. The aim is to examine current knowledge on IBOs in entrepreneurial internationalization. We assess the manner and extent with which entrepreneurial internationalization research studies opportunities and relates with the conceptualizations of entrepreneurial opportunities reviewed above. The following sections describe the methods we followed to indentify and analyze the articles.

\section{Identification of the relevant literature}

The articles were selected through a stepwise process following by large the protocol by 
Kitchenham (2004) that supports the aim of making the search for research both systematic and comprehensive. The selection procedure is very similar to that followed by Grégoire et al. (2010) in their review that aimed at developing a conceptually sound research agenda for future research. First, the business and management journals that achieved an ISI-impact factor of over 1.000 in the 2009 ranking were selected (83 journals). Secondly, we crosschecked that listing with the ten most influential international management journals as ranked by Acedo and Casillas (2005) and the dedicated entrepreneurship journals as ranked by Katz and Boal (2002). This led us to add the Management International Review and the Journal of International Management. Then the Journal of International Entrepreneurship was added because it specializes in the topic. Finally, the European Management Journal was added on the grounds that it published a special issue on IE in 2008 and has continued to publish IE articles. Protocol for identifying relevant entrepreneurial internationalization literature is presented in Table 2.

Insert Table 2 about here.

The search was delimited to articles published 1989-2010 (including articles in press in 2010), which should encompass the full scope of the field. It should be noted that the review covers only articles published in journals, and does not extend to a systematic search of books or book chapters. Although a deliberate choice, we recognize it as one that may have caused some influential contributions to be overlooked. Nevertheless, we see the delimitation is arguable on the basis of the quality of review processes inherent in highly-ranked journals and on the basis of accessibility of the articles.

The selection of the articles had three rounds. The first round was intentionally wide in scope, in that all possible IE articles were selected. It started with a manual review of each 
published number of each journal picking up all articles possibly dealing with entrepreneurial internationalization. The authors, then, searched the journals through keywords 'international entrepreneurship', 'entrepreneurship', 'small business', 'opportunity', 'international' and 'internationalization' to reduce subjective interpretation bias. We also examined the citations to Oviatt and McDougall (1994) article and the references of the previous IE reviews with cross-disciplinary emphasis (Coviello and Jones 2004; Jones at al. 2011).

In the second round we directed our attention to the conceptual bases of the articles. As IE was defined as a field that intentionally combines international business and entrepreneurship, the chosen articles used both internationalization/international/born global/export and entrepreneurship/ entrepreneurial/ entrepreneur in their titles, abstracts or key words. We then ensured that the articles explicitly incorporated concepts from both international business and entrepreneurship research in their theoretical development by reviewing the theoretical sections of the studies. This criterion is consistent with the criteria used by Coviello and Jones (2004) and Jones et al. (2011). Our selection excludes articles that studied the internationalization of SMEs without the use of entrepreneurship theory seeing small firms or new ventures primarily as interesting contexts for internationalization research. Use of data collected from different countries to study entrepreneurship was not sufficient to ensure selection unless international business theory was also used. Furthermore, relating to the early, and undeniably very influential, international new venture or born global research (e.g. Autio et al. 2000; Madsen and Servais 1997; Oviatt and McDougall 1994) was not sufficient. It would have caused a circular definition of IE research instead of stressing the cross-disciplinary nature of the field. The rejected articles were double-checked and uncertain cases reviewed jointly by the researchers. Through this procedure we selected 143 IE articles from 24 journals. We identified also 25 general level reviews, editorials and commentaries providing overviews of the field. They have inspired our view of IE as a field, 
but these articles are excluded from the detailed examination.

In the third round of selection researchers examined each of the 143 articles. The aim was to assess whether the articles incorporated the concept of IBO. The occurrences of the word 'opportunity' in each study were recorded and the contexts of the concept use were analyzed. We chose articles that reported opportunity as a concept in the research objective or theoretical framework, as a variable in a questionnaire or a topic in an interview guide or in conceptualizing and modeling the research results. In this way we aimed to find those articles that have intentionally used the concept with a specific meaning even if they did not define it as a key concept. The articles that used opportunity as a common expression or in single sentences were excluded from the in-depth examination. To summarize, we included the articles that explicitly used the concept of opportunity as a theoretical and/or empirical concept of interest. The 73 articles that were excluded from the in-depth examination combined international business and entrepreneurship theories but did not address opportunity with the specific meaning described above. The journals and the number of articles analyzed are presented in Table 3.

Insert Table 3 about here.

\section{Coding procedure and analysis methods}

In the analysis we used the content analysis procedures typical of grounded theoretical analysis (Strauss and Corbin 1990) with three specific phases of coding: open coding, axial coding and selective coding (see Table 4). In the open coding phase we used both data-driven (emic) codes and theory-led (etic) codes (Pike 1967). This makes it possible to study the articles both from inside (categories that emerge from data) and from outside (categories 
derived by researchers based on the previous research). We followed, by large, the metanarrative analysis procedure as presented by Greenhalgh et al. (2004).

Insert Table 4 about here.

Two of the researchers independently coded the articles. We started with a detailed examination of the research objectives and theoretical frameworks of the studies to define entrepreneurial internationalization phenomena of interest. Through data-based coding of the research questions, theoretical bases and the fields of intended contribution we depicted the research focuses and conceptual foundations of the studies. We then moved on to theory-led coding to examine how the studies approached the IBOs. We recorded their definitions of opportunities, if provided, and how their discussed opportunities either as entities to be recognized or as developing processes of creation. The conceptualizations presented in Section 2.2 worked as a frame of reference but we soon noted that the articles seldom discuss opportunities clearly and in-depth in these terms. We, therefore, recorded the entrepreneurial opportunity literature their relied on in their conceptual discussion and their findings on IBOs and IBO-related behaviors. This means that we examined each study more as a whole to assess it as a piece of research from the opportunity-focused viewpoint rather than searched for certain variables or words. That way we aimed to uncover the specificities of entrepreneurial internationalization research in relation to IBOs, which should influence the research agenda.

In the axial coding we searched for studies with similar conceptual bases and similar kinds of approaches to IBOs. We recorded unifying concepts and relationships between them in relation to IBOs. In the selective coding the aim was to create a basis for defining research streams on IBOs in entrepreneurial internationalization. Each research stream can be seen to 
present a similar kind of basic approach to context, conditions, actions, interactions and outcomes of the phenomenon. This was the primary phase of appraisal in which we evaluated the articles with respect to their relevance for IBO-focused research and organized and grouped them on the basis of their key results.

On the basis of the coding and classification of the articles we report a synthesis of the observations we made in the following Section 4. We depict four streams of entrepreneurial internationalization research in terms of their viewpoints and conceptual bases adopted on opportunities and their key findings on IBOs and IBO-focused behaviors. We produce a narrative account of the conceptual foundations and contributions of each stream of research on which the future research could rely. The conceptualizations presented earlier work as a vehicle for theorizing the nature of IBOs and the behaviors that relate to them.

\section{Results of the review}

The 70 IE articles that incorporate the concept of opportunity provide a reasonable basis for analyzing the approaches to IBOs in entrepreneurial internationalization research and the related findings and contributions. Our analysis indicates significantly increasing interest in international business opportunities towards the end of the period 1989-2010. We identified McDougall et al. (1994) and Oviatt and McDougall (1994) as the first entrepreneurial internationalization articles incorporating IBO as a concept. As a whole, however, in the 1990s only seven articles using the concept of opportunity were found. In the second half of the period, opportunity seems to become a common concept of entrepreneurial internationalization research as 63 articles incorporate the opportunity concept into their studies. 
Findings and contributions of entrepreneurial internationalization research on IBOs

We review the conceptual foundations and primary findings in relation to IBOs in four research streams that we defined as a synthesis of the analyses of the articles. We aim to depict what we know about IBOs in entrepreneurial internationalization on the basis of empirical research and what conceptual ideas have been put forward for further examination. The four research streams of reviewed studies on IBOs in entrepreneurial internationalization are presented in Table 5 .

Insert Table 5 about here.

Realization of IBOs in INVs and MNCs. The first stream of research includes 27 studies whose focus is on factors influencing the formation of INVs and the renewal of MNCs on the basis of IBO discovery. They are relatively firmly rooted in the entrepreneurship literature and bring IBOs within the realm of entrepreneurial internationalization research through their building on Kirzner's or Schumpeter's original ideas. Entrepreneurship is, in general, seen as identification and/or exploitation of opportunities.

The first half of the studies builds on the study by Oviatt and McDougall (1994) in which they nominate the discovery of an IBO as the antecedent of early internationalization characterizing INVs. Since then, ten empirical studies suggest a variety of capabilities required for the realization of IBOs in INVs and three studies focus on capabilities needed in MNCs. Typical of these studies is Kirznerian view to entrepreneurship and related emphasis on alertness as a key characteristic and knowledge as a key determinant of IBO-focused behaviors. 
McDougall et al. (1994, p. 479) suggest alertness as a critical entrepreneurial capability and point to market disequilibrium as a basis for opportunities, which are "information about potentially profitable resource combinations". They show entrepreneurs' alertness to IBOs be based on their earlier activities and unusual competences (such as networks, knowledge and background). Entrepreneurs of INVs develop specific routines for managing multicultural workforces, for cross-national coordination of resources and for targeting customers in many locations at the same time and use hybrid organizing methods to realize the IBOs in INVs. According to Autio et al. (2000) the competence to discover and exploit IBOs in INVs relates to the capabilities of rapid learning and knowledge accumulation. The lack of established cognitive structures pulls new firms forward to learn appropriate international business skills. However, the early pursuit of international opportunities might risk the company as a later study proposes that early internationalization possibly permits growth but threatens survival (Sapienza et al. 2006).

Alertness to opportunities or opportunity identification across national borders are depicted as core INV capabilities in several later studies too (Evangelista 2005; Isenberg 2008; Karra et al. 2008; Kuemmerle 2002). According to Kuemmerle (2002), it is difficult to find IBOs from beyond our own industry sphere. Although the experience might cause cognitive path dependency, it also makes it possible to understand the gaps and the need to renew the knowledge. Karra et al. (2008) name opportunity identification as one of the entrepreneurial capabilities necessary for success of INVs. Sequeira et al. (2009) show the transnational entrepreneurs' perception of the availability of opportunities influence the type of the established enterprise. De Clercq et al. (2010) note institutional contexts and networks to be situational elements that influence new opportunity identification.

Birkinshaw (1997) also defines entrepreneurship as alertness to market opportunities and this capability to be critical for renewal of MNCs. He sees opportunity identification as the 
basis of subsidiary initiatives, which advance a new way to use or expand the MNC resources. In MNCs, IBOs involve not only creating new business, but enhancing the ability to respond to local needs, to support learning and to foster global integration of resources and processes. We consider the study seminal because it shows IBOs to be important MNC phenomena and IBOs to exist in domestic markets too - when the resources to serve the domestic market are organized through cross-border activities and resource combinations. Other studies in the MNC context have disclosed some behaviors and capabilities related to IBO discovery. Boojihavon et al. (2007) suggest that it is the entrepreneurial subsidiaries, in particular, that scan the network for opportunities. Zahra and Hayton (2008) show that the relationship between opportunity exploitation in international venturing and performance is not straightforward but moderated by absorptive capability.

Four conceptual studies also build on Kirznerian opportunity recognition as the core of new business creation. Zander (2004) emphasizes that local clustering of economic activity prohibits IBO recognition because the locally oriented knowledge determines the cognitive processes of opportunity identification. Di Gregorio (2005) posits the cognition of risks associated with international markets as a major impediment for international venturing, noting that entrepreneurial opportunities are greatest when market conditions are inherently unpredictable. Muzychenko (2008) emphasizes the influence of cross-cultural environment on the cognition of IBOs and suggests cross-cultural competence needed to deal with cultural, historical and national differences and to use them as resources in identification and exploitation of IBOs in INVs. Webb et al. (2010) state the importance of institutional contexts in determining opportunity-focused entrepreneurial activity. They suggest MNCs and NGOs are together capable of changing the context, especially to support new social value creation.

Acs et al. (2001) in their conceptual study see innovation as the core of entrepreneurship. 
Internationally operating firms have the capability to see and capture innovation opportunities and are "vehicles for internationalizing Schumpeterian creative destruction" (ibid, p. 239). Nevertheless, in line with the above studies, they emphasize the importance of resources and capabilities to bring the innovations to international markets. Knight and Cavusgil (2004) also build on Schumpeter to define internationalization as an innovative act in which capabilities and routines for innovating are important determinants of an organizational culture that leads to success for INVs. Park and Bae (2004) focus on the strategies employed in identifying opportunities. They distinguish the strategies on the basis of market maturity and technological capabilities involved and underline the importance of specific technological knowledge to be able to innovate new solutions. Kropp et al. (2006) delimit opportunity identification as one element of Schumpeterian innovativeness which, in turn, is one element of entrepreneurial orientation.

Six conceptual studies suggest both Kirznerian alertness to opportunities and Schumpeterian capability to innovate as the basis of international entrepreneurial activity. The alertness and innovativeness should lead to venturing on the basis of effective resource recombination (Zahra et al. 2001). These capabilities are suggested to characterize especially entrepreneurial communities in MNCs (Lee and Williams 2007; Mahnke et al. 2007). Lee and Williams (2007) underline the multinational and multicultural border zones in which these communities assemble and bring their cultural resources and practices to construct new IBOs in collaborative and unorthodox ways. IBOs are also seen especially likely to arise at the intersection of various, often rival or controversial, interests (Mahnke et al. 2007). Different types of political settings can result in different types of IBOs (Williams and Lee 2009). To Matthews and Zander (2007), international entrepreneurial dynamics are based on entrepreneurial identification of opportunities either from asymmetrically dispersed knowledge or from latent combinations of resources. Di Gregorio et al. (2008) present one of 
the few studies that try to conceptualize different types of IBOs. They differentiate cross border resource integrators with opportunities that entail novel resource combinations, accelerated international sellers with opportunities that entail novel market combinations and those combining both types of opportunities in their venturing. Entrepreneurial activity on opportunities is about "creating and resolving differences in knowledge and resources across time and space" (ibid, 187).

Taken together, most of these studies depict IBOs as possibilities to combine dispersed knowledge or latent resources into INVs or new uses in MNCs. The strength of the stream in relation to knowledge on IBOs in entrepreneurial internationalization is the acknowledgement of IBOs in initiation of the international entrepreneurial behavior. Still, the studies are primarily about international venturing on the basis of the assumed discovery of an opportunity and capabilities needed in opportunity exploitation, not about IBOs or their discovery, as such. Several studies emphasize the influence of the context on the IBO discovery. However, the research is to a large extent conceptual and the interesting ideas put forth, especially in relation to IBO related behaviors in MNCs, lack empirical elaboration and testing.

International market arbitrage as the basis for international business. Another stream of research focuses on international market entry. The 32 studies in this category primarily examine what kind of strategies and orientations make it possible for firms to capture arbitrage opportunities in international markets through internationalization of their activities. They view opportunities as external to the firm (in the market) and firms as in possession of advantages and hindered by certain limitations impacting the capture of those opportunities.

The early studies (Karagozoglu and Lindell 1998; Preece et al. 1998) just used the IBO concept in their questionnaires, asking if the management has the time and competence to 
analyze and exploit IBOs. As opportunity becomes an explicit part of the models of the studies, IBO is seen as a stimulus for internationalization (e.g. Crick and Jones 2000; Crick et al. 2001; Oviatt and McDougall 2005; Perks and Hughes 2008) or opportunity identification as the first stage of the internationalization process (e.g. Han 2006; Prashantham 2008; Zhou 2007). Often the studies discuss greater opportunities in international markets as motives for internationalization but do not theorize about those opportunities (e.g. Crick 2007; De Clercq et al. 2005; Liu et al. 2008; Mittelstaedt and Ward 2006; Shaw and Darroch 2004). The research also suggests that the entrepreneur or firm needs to act quickly when windows of opportunity present themselves in specific country markets depicting discovery view of the behaviors (e.g. Acedo and Jones 2007; Crick and Spence 2005; Liu et al. 2008; Nordman and Melén 2008).

Most of the research in this stream is quite loosely connected to the entrepreneurship research and, in general, pays limited attention to IBOs and their recognition. However, it does suggest some determinants of opportunity identification - the first of which is networks. Sullivan-Mort and Weerawardena (2006) show how networks assist in overcoming the resource constraints faced by SMEs and so present opportunities while simultaneously delimiting opportunity identification within the existing network. Lorentz and Ghauri (2008) illustrate how solid embeddedness in local networks is important for recognition of opportunities in the Russian market. Sasi and Arenius (2008) suggest that it is the networks of the founders, not the firms, which influence international opportunity identification. Styles and Genua (2008) also consider the personal networks of academics to support the identification of initial opportunities to internationalize in research-based start-ups. On the contrary, Kontinen and Ojala (2011) demonstrate that in terms of recognition of possibilities for international exchange by family SMEs, weak ties are more important than strong ones.

Entrepreneurial orientation and international growth orientation are seen as the cognitions 
that affect the perception of IBOs and accelerate international expansion. Acedo and Jones (2007) illustrate that it is the tolerance of ambiguity that assists -and risk perception that prevents- recognition of opportunities for internationalization in SMEs. Liu et al. (2008) suggest the Chinese transition context leads to bounded entrepreneurial cognition of international opportunities, which in turn leads to gradual internationalization. Dimitratos et al. (2010) highlight the proactive attitude towards opportunities that is based on interaction with customers and partners in their lead countries to be the entrepreneurial cognition that underpins small global firms. Several other studies examine entrepreneurial orientation in internationalizing firms but are unclear in terms of how they see opportunity recognition involved.

Crick and Spence (2005) and Spence and Crick (2006) point out that entrepreneurs and managers recognize and exploit opportunities in different ways - ways that range from planned strategy formation through to opportunistic behavior as a response to serendipitous encounters. Nordman and Melén (2008) support the view by illustrating 'born industrials' that search for opportunities internationally, whereas 'born academics' discover opportunities by chance as a consequence of their ongoing foreign market activities. With their cases on knowledge-based firms, Chandra et al. (2009) suggest that initial international market entry by internationally inexperienced firms, in particular, is a process of opportunity discovery, rather than a result of deliberate searching. Dana et al. (2009) support the studies that expect different kinds of entrepreneurs behave differently as they distinguish 'reactive' entrepreneurs who respond to environmental push and 'opportunity seeking' entrepreneurs who respond to both push and pull of the environment.

Overall, the strength of the stream is the empirical grounding of the claims on IBOinitiated accelerated internationalization. The research results with respect to the role of networks and entrepreneurial cognitions suggest these as key determinants of international- 
opportunity-based entry. However, although the studies note the IBOs as triggers for accelerated internationalization and many acknowledge opportunity recognition at the start of internationalization the opportunities are not deeply studied. The opportunity in question is primarily the opportunity to internationalize and is not characterized further as an entrepreneurial opportunity. The five studies on intentionality of opportunity discovery provide initial basis for further study on those behaviors.

The context embeddedness of IBO development over entrepreneurial processes. We see five studies suggesting a third, emerging stream of research that emphasizes the socially constructed and dynamic nature of IBOs. The studies are firmly rooted in entrepreneurship research and focus on how entrepreneurial activity is embedded in and takes place across national, cultural, historical and other social contexts. Baker et al. (2005) contrast with the objective notion of opportunities and claim every opportunity to be subjective and context dependent as the opportunity is enacted by individuals. They propose subjectively interpreted elements of social context, such as division of labor, opportunity costs and available resources affect what is perceived as an opportunity and how IBOs develop in the entrepreneurial processes. Similarly, Zahra et al. (2005) advocate the cognitive perspective because it would allow examination of IE as an individual's sense-making process, in which an opportunity unfolds over time under specific social circumstances. Both studies suggest such issues as entrepreneurs' motivations and the geography, history and culture in which they are embedded are important to the enactment of IBOs.

The empirical research along these lines is scarce. Through a longitudinal case study McGaughey (2007) illustrates how a portfolio of businesses provides a field of experimentation with new ideas and so creates a favorable context for the emergence of IBOs. Mainela and Puhakka (2009) show how entrepreneurial managers are absorbed into the 
emerging social community of the joint venture and in their IBO development benefit from the influences of others in the community. In line with the conceptual studies, they stress the cognitive activities of individuals in interpreting the multicultural environment of the IBOs and show how that relates to personal initiatives over time. Nasra and Dacin (2010) demonstrate how state action in the United Arab Emirates has changed the institutional context and influenced entrepreneurial opportunities in Dubai.

All this suggests a need to appreciate the social setting and to locate IBOs into a wider context to understand how they emerge and are enacted over time. The studies denote the nature of IBOs as iterative processes driven by cognitive activities (rather than orientations) of individuals. In all these studies IBOs are seen to be a result of sense making and enactment in a continually changing social situation. We consider these ideas of specific importance to further research on IBOs, while acknowledging the need for greater attention to the conceptualizations of the IBOs.

IBOs resulting from actions and interactions in daily business activities. Six studies initiate a fourth stream of entrepreneurial internationalization research. The studies build especially on the Kirznerian view of opportunities as arbitrage and examine how IBOs are developed in a process of acting in internationalization of the firms. The stream brings forth the action-based and interactive nature of the IBO development.

To Hohenthal et al. (2003) opportunity is an unanticipated discovery in the market resulting from being perceptive and creative in the internationalization process. They define opportunity as a gap between supply and demand in disequilibrium markets. IBOs emerge from everyday practices of exploration and exploitation and are primarily answers to some unanticipated questions. IBOs result from being perceptive and creative in the international market entry process. Concurrently, Johanson and Vahlne $(2006,2009)$ define opportunities 
as

socially constructed market knowledge but depict IBOs as created in interaction. Interaction with others creates privileged knowledge, which can be combined in new ways, and then can lead to new businesses opportunities. Further, while partners learn about each other's needs, technology and relationships, ideas gradually take form and the partners are more likely to find the commitment necessary to realize the IBO. This makes networks a part of the content of IBOs, not merely an environment for them to thrive in. Chandra and Coviello (2010) suggest co-developing with consumers to be the way to market and create products and services internationally. They discuss how individual consumers may act as Schumpeterian international outsources and international innovators and producers and cocreate innovation opportunities. Some others act as Kirznerian international traders and international financiers when they get involved with existing businesses to market their products and services.

Two empirical studies (Fletcher 2004; Schweizer et al. 2010) illustrate internationalization as a reflection of the entrepreneurial process instead of it being an act based on a deliberate plan. Both reveal how IBOs are developed through cross-border interaction in networks in which the knowledge, resources and exchanges become organized according to the developing opportunity. Contrary to the studies in the previous stream these studies posit that instead of acting alone, entrepreneurs act within relationships during the whole process of IBO development.

Like the third stream this one is also represented by only a few studies, most of which are conceptual. However, we consider them to make an important contribution in raising the possibility that IBOs might be a continuum of expansive developments from entrepreneurial acting and interactions with others. This means a focus on such aspects as daily practices, dialogues, exchanges and joint acts in the IBO creation. 


\section{Discussion}

The motivation behind this review study was the definition of IE by Oviatt and McDougall (2005) that we saw necessitate further attention to IBOs. We argued in the beginning that the IBO seems to be a concept that connects the viewpoints of internationalization and entrepreneurship researchers and therefore holds significant integrative potential in this interdisciplinary field. Simultaneously we noted that the research on entrepreneurial opportunities provides us with several conceptualizations of opportunities that could be used as the conceptual bases for developing research on IBOs in entrepreneurial internationalization further. However, the research agenda also needs to build on the specificities of entrepreneurial internationalization as a research phenomenon and elaborate on the current knowledge and research gaps on IBOs in that field.

For that purpose we conducted a detailed review of 70 articles that incorporated opportunity as a concept into their studies. The review has certain limitations that need to be recognized. First, the review was limited to the period 1989-2010 and covers only articles from the business and management journals with a citation index of over 1.000 (in 2009) and a couple of other journals considered relevant. Second, the articles were selected based on relative criteria and not absolute measures and this can lead to a certain bias in selection, although two researchers carried out the selection and followed a carefully planned process. Third, we selected only articles that explicitly used opportunity as a theoretical or empirical concept and did not look for studies using alternate concepts to describe the phenomenon. Fourth, the study does not cover comparative IE studies. These choices have an influence on the coverage of the review and the generalizability of the results to the IE field.

Another set of limitations arises from the challenges of interpretive research on abstract concepts such as an opportunity. First, we needed to judge the importance attributed to the 
concept in the studies and whether that merited selection for in-depth examination. Opportunity is a common expression used when describing many courses of action, and so determining if it has any specific meaning in the study is an interpretive task. Second, the lack of explicit definitions of an IBO or clear notions on the approach to IBOs required interpretive effort in determining the streams in relation to IBOs. We applied two procedures to overcome the subjective interpretations. We outlined established conceptualizations of opportunities from the entrepreneurship research to establish a common basis for the review. Every article was also analyzed by two of the authors to validate the interpretations and the different opinions were discussed until agreement was reached (cf. Jones at al. 2011). Overall, we followed the process of qualitative content analysis but accept the possibility of some bias due to the lack of absolute measures and clear-cut decision rules.

To summarize the results of the review, we find that a good portion of the entrepreneurial internationalization research to date has referred to the variety of IBO-initiated behaviors. Overall, however, although research often accentuates the centrality of opportunity recognition, exploitation and enactment in IE, we rarely find an in-depth analysis of the IBO as the object of the behaviors or of those behaviors themselves. This can partly be accounted for by the quite recent explication of IBOs at the core of IE, which means that the opportunity is not yet often among the key variables or elements of the study. The other part might be related to the difficulty of defining those very IBOs.

Our review did not allow for a clear division of the studies in terms of the four conceptualizations of opportunities we presented theoretically. The IE research quite seldom discusses opportunities clearly in these terms. However, the conceptualizations signify how the IBO is a more complex concept than the IE research to date would indicate. Moreover, many researchers (e.g. Aspelund et al. 2007; Di Gregorio et al. 2008; Fletcher 2004) assert that it is the duality of innovative venture creation and international market arbitrage in both 
INVs and MNCs that makes IE special. Therefore, the relationships between innovation and arbitrage in IBOs might be an interesting topic of future research (see Anokhin et al. 2011). We suggest that the creative-cognitive approach from our agenda could be especially useful there. It acknowledges the cognition based interpretations of market gaps as well as the creativity by the entrepreneur.

The opportunity discovery and opportunity creation, in turn, have been approached both as a continuum of behaviors (e.g. Ardichvili et al. 2003) and as ontologically and epistemologically different issues (Alvarez and Barney 2010). In a continuum some research has suggested ways in which the behaviors are intertwined and the possible dominance of either one or another over time (e.g. Johanson and Vahlne 2009). Several studies also suggest international entrepreneurs behave differently in different circumstances depending on, for example, earlier experience or type of business environment (e.g. Chandra et al. 2009; Nordman and Melén 2008). The context embeddedness approach from our agenda could be used to examine how different national, historical, cultural, organizational and other socially defined settings might induce and support either type of behavior. The knowledge of the influence of situational factors in determining IBOs and ways of IBO development is still in its infancy.

The philosophical view leads to either more objectivist or more subjectivist research and the latter is currently quite underdeveloped in IE research. By conceptualizing IBOs as created, we can depict the enacted reality that characterizes much of the entrepreneurial internationalization (Alvarez and Barney 2010). We might also conceptualize IBOs as existing phenomena, which are, however, not readily available for exploitation by entrepreneurs and managers, but which are socially constructed (cf. Fletcher 2004). Such a practical realist stance (see Bhaskar 2008; Sandberg and Tsoukas 2011; Shepherd and Sutcliffe 2011; Tsoukas 1989) brings with it the potential to increase the amount of 
explanatory knowledge, seen as the generative mechanisms that drive IE processes. The interaction-focused and practice approaches from our agenda have the enactment of reality inherent in them. They go beyond the structural and strategic factors explaining IBOs and set out the multifaceted reality in which entrepreneurs actualize IBOs.

\section{Agenda for future research}

Our research agenda suggests, in particular, paying increased attention to IBOs themselves and the processes through which an IBO becomes an IBO in entrepreneurial internationalization. To encourage future research into this direction, we suggest the following definition of an IBO: An IBO is a situation that spans multiple national contexts in which ideas, beliefs and actions to create economic value are manifested as new business activities.

We intend the definition to allow for the study of IBOs with any individual conceptualization presented in Section 3.2., or any combination of them. Manifestation as new business activities involves both innovation and arbitrage opportunities. However, we consider it important to note that innovation and arbitrage opportunities significantly differ from each other in terms of value creation and competitive imperfections. In innovation opportunities value creation is primarily based on novelty value that creates competitive imperfection as in the case of disruptive innovations, for example. The value creation in arbitrage opportunities is primarily based on unsatisfied market needs whose fulfillment decreases competitive imperfection. An opportunity might also change over time from one type to another (see e.g. Zahra 2008). Therefore, future research should pay attention to the features of the different manifestations of opportunities.

The definition should also allow for study of both opportunity discovery and opportunity 
creation. The discovery view focuses on the elements of the situation, such as resources, markets and products, determined as means and ends involved in the IBOs. The creation view focuses on the human perception and acting in the specific situation. Combining the two sides of the definition leads to the ontological and epistemological middle ground (see Merton 1967; Pinder and Moore 1980) where characteristics of the situations generating opportunities are seen as real but entrepreneurial interpretation and construction is required to actualize the opportunities.

Furthermore, for a situation to be an IBO it must involve at least two countries. We consider it important to take the international element beyond the simple notion of exchange across national borders. The research should explicate the features of the cross-border situation and how the cross-border nature actually influences the IBOs and their development.

Inspired by the observations presented, we proceed to suggest research questions, theoretical frameworks and methodological choices for future research on IBOs. We propose four primary directions that entrepreneurial internationalization research with an IBO focus might expand into.

\section{The creative-cognitive approach to IBOs}

The first research direction takes a creative-cognitive approach to IBOs. Several of the studies that we reviewed did pay attention to cognitions as determinants of behaviors in entrepreneurial internationalization (e.g. Acedo and Jones 2007; Autio et al. 2000; Di Gregorio 2005). We propose more attention to be paid to the cognitive processes and cognitive framing of situations in the discovery of IBOs. The interest lies, in particular, in the changing perceptions and cognitive models of sense-making (see Mitchell and Shepherd 
2010; Zahra et al. 2005) rather than static orientations. In the study of cognitive processes related to IBO discovery, we consider it important to acknowledge the influences of the cultural and national settings as suggested by some of the studies in the review (e.g. Crick et al. 2001; Zander 2004).

During the cognitive development of IBOs, entrepreneurs not only search for information in local and foreign environments, but also construct new knowledge structures that form the IBOs (Johanson and Vahlne 2009). Creative thinking is the driver of this process (cf. Kirzner 1997) because the multicultural, national border-crossing situations in which IBOs are present are too complex and dynamic to allow rational deduction of correct answers from examination of their elements (see e.g. Cornelissen and Clarke 2010). This impels the creative entrepreneurial mind to search for a novel solution that combines elements from multiple national contexts. Therefore, future research should acknowledge an IBO to be about creating a meaning based on information gathered from around the world that may well be historically, culturally and socio-economically ambiguous, rather than arriving at a single decision based on given information.

This approach requires adopting the cognitive process of international entrepreneurs in their definition of the IBOs as the unit of analysis. Researchers need to be able to collect data and analyze the ways in which the entrepreneurial mind arranges the pieces of information, relates them to one another, and thereby creates a new knowledge structure, an IBO. Cognitive psychology could provide conceptual and methodological tools for this research. For example, schema theory sees information we perceive as codified, made sensible and stored in our minds as organized maps of situations, people and experiences. We might also study heuristics and cognitive styles as determinants of IE decision making. This would allow us to go beyond the determinants of the complexity of INV formation or accelerated internationalization towards understanding how international entrepreneurs manage that 
complexity and make sense of it to create new international business. The questions of interest include, for example: How do international entrepreneurs cognitively frame IBOs? What are the sense-making schemes that are activated in different cross-border situations of IBO discovery? What kind of culture-based heuristics and cognitive biases lie behind different IBOs? How do international entrepreneurs act creatively in proactive sense-making of IBOs?

\section{The context embeddedness approach to IBOs}

The context embeddedness approach to IBOs starts with entrepreneurship research that sees opportunities strongly influenced by the specific social settings (see e.g. Dana 1995). Several of the studies that we reviewed underline the importance of contexts and social situations based on which IBOs arise (e.g. Baker et al. 2005). It might be the border-crossing settings combined with controversial interests, in particular, that favor the emergence of IBOs (e.g. Lee and Williams 2007; Mahnke et al. 2007; Williams and Lee 2009). MNCs in particular are seen as settings in which various cultural or expertise based communities co-exist and create a need to solve issues. Firms entering new markets often also create new opportunities through exploiting ideas, feedback and learning from their exchanges with local individuals and entities (Webb et al. 2010).

The spanning or integration of multiple national contexts is, thus, a necessary driver of IBOs and the very combination of the contexts the origin of the novel means of value creation. This stresses acting on the border zones in which the international uncertainties are not hindrances to be overcome but create a context where actors develop new IBOs. IBOs cross not only national but historical, cultural, organizational and other social communitybased borders and the act of crossing those borders is crucial for the emergence of IBOs. 
The approach requires using the international context as the unit of analysis and might need intensive data collection at the level of communities or other relevant social contexts to understand IBOs and their development. In this kind of study, researchers inevitably need to deal with several levels of analysis as the interaction between the contexts, entrepreneurial acting and the IBOs must be clarified. We support the use of the 'MNCs as networks' view and institutional theory as the theoretical approaches, particularly in combination with entrepreneurship research. In-depth case studies create a deep understanding of a particular social setting and a base for theorizing on the phenomenon in relation to its context. Furthermore, the process approaches involving examination at various interaction levels should be used (see e.g. Buttriss and Wilkinson 2007). Interesting questions include, for example: How does the social setting in which the IBO is embedded influence the behaviors of IBO development? How can national, historical, cultural and other social differences be used as resources in the creation of IBOs? How do international entrepreneurs solve and make use of conflicts of interest arising in IBO discovery, creation and exploitation in MNCs?

The interaction-focused approach to IBOs

The third research direction is about processes of interaction in IBO development. It starts with the entrepreneurship research emphasizing creation of opportunities as a dialogical process of enacting the opportunity through involving others in the development (e.g. Fletcher 2007). It then builds on the view that interactions in the international partnerships and customer-supplier and institutional relationships are the basis for new opportunities, often created at the edges of the multinational networks (De Clercq et al. 2010; Johanson and Vahlne 2009; Sequeira et al. 2009). As IBO development is a process of interacting in 
relationships to create shared interests, all the actors involved become parts of the IBO (Schweizer et al. 2010). This makes IBOs collective.

According to this view, the IBO inevitably reflects how international entrepreneurs relate to and interact with others and the availability of others to jointly enact the IBO. This approach emphasizes that an IBO is discussed, interpreted and produced between various actors from different markets and the challenge, therefore, is to uncover these interactions. It is an approach that might be expected to result in an understanding of the processes through which actors representing different organizations create collective opportunities.

This approach requires adopting the interaction within relationships as the unit of analysis. Analysis at the relationship level, then, requires collecting dyadic data and being able to compare and combine the views of the various actors. The research on business-tobusiness relationships and interactions and exchanges within them provide both theoretical and methodological tools for this kind of study. In-depth, narrative interviews (Pentland 1999) and observation of communications between the parties involved often produce good accounts of the interactions. Social network analysis has also been used to study interactions in international relationships (e.g. Coviello 2006). The research could as well make use of the data produced in the normal business exchange between companies, such as business correspondence, memos, minutes of the meetings and emails (see Wakkee 2006). The questions of interest include, for example: How are IBOs created in interactions occurring within particular international business relationships? What are the determining features of collective IBOs? How are the dynamics of international business relationships reflected in the development of IBOs over time?

The practice approach to IBOs 
The fourth research direction would develop a practice approach to IBOs. It could start with the view of entrepreneurship as effectuation (Sarasvathy 2001). Effectuation logic focuses on converting uncertainties into opportunities based on the means available at the moment and without trying to predict the future. The approach, then, builds on the basic assumption of international business research that in internationalization the firms encounter uncertainty and surprises as a result of national and cultural differences and solve those along the way (e.g. Johanson and Vahlne 1977). The approach is emerging in the IE research that illustrates how firms create international business through international entrepreneurs' action (e.g. Fletcher 2004; Hohenthal et al. 2003; Mainela and Puhakka 2009; Schweizer et al. 2010). IBOs are shown to result from everyday activities of international entrepreneurship in both its routine and improvised forms.

Although the entrepreneurial practice as suggested by the effectuation logic and the latest IBO creation research is one element of the practice approach, we suggest taking the view further with theoretical and philosophical considerations on practice (see Feldman and Orlikowski 2011). The theoretical dimension focuses on the activities of international entrepreneuring, but goes further in the search for an explanation of how IBOs emerge from the continuous interplay between situational structures and entrepreneurial agency. The methodological dimension of the practice approach rejects the basic division into objectivist and subjectivist philosophies. The national, industrial and cultural structures of business are seen as real as they compel entrepreneurs to behave in certain ways. However, the IBOs as the objects of the behavior are socially constructed through the everyday practice of the entrepreneurs and those activities reproduce and transform the structures. Therefore, the structures too are always in the making and the practices are the primary building blocks of social reality. The practice approach is the most useful when studying phenomena that are complex, dynamic, distributed, transient and unprecedented (Feldman and Orlikowski 2011). 
We suggest that those are the characteristics of many present day IBOs.

This approach requires adopting the entrepreneurial practice as the unit of analysis (see De Clercq and Voronov 2009) and following how normal tasks in entrepreneurs' working lives generate IBOs. Data collection on practice necessitates getting close to international entrepreneurs to observe and record their actions when they are actualized. IE researchers could mimic the strategy-making and knowing-in-practice approaches in organization studies to uncover how entrepreneurs organize the IBOs both conditioned by and creating the social structures of international business. Storytelling (see Gartner 2010), self-reporting and various dialogical methods provide a good basis for analysis of written, spoken or symbolic language that helps understand the embedded structures of practice. The international business practices that take place over various electronic interfaces (such as virtual meetings, online chat or open source teamwork) also produce data that would reveal practices behind the creation of the IBOs that increasingly characterize global business. Intriguing questions raised include, for example: How do IBOs emerge from the everyday practice of international entrepreneurs in relation to their social contexts? What are the practices of concretizing the IBOs as the objects of international entrepreneurial behaviors? What are the generative processes of IBO creation reflected in the practices of international entrepreneurs over time? How do the IBO-oriented practices recreate and transform industries and other social realities?

\section{Conclusions}

We discussed the concept of opportunity in entrepreneurship research and in entrepreneurial internationalization research. We defined various conceptualizations of opportunities, in general, and identified research streams, the elements stressed and the key findings of 
entrepreneurial internationalization research, in particular, before examining the research gaps and potential avenues for future research. Many studies examine variables, such as unique competencies, entrepreneurial orientation, learning orientation and networks in relation to the establishment or growth of international new ventures or in relation to new international market entries and operations. Research inquiring analytically into the nature of IBOs is rare. Research also predominantly treats IBOs as quite concrete objects that are recognized by alert individuals, and there is a notable scarcity of research that pays attention to the processes of IBO creation over time. Our view is that research that builds on the latest definition of IE by Oviatt and McDougall (2005) and therefore focuses on IBOs, should increase the effort it makes to examine IBOs per se.

Nevertheless our review suggests that there is quite a widespread acknowledgement of entrepreneurial internationalization behaviors being IBO-oriented. If this basic claim is combined with the longer tradition of opportunity focused research and existing views on opportunities in entrepreneurship, future research should have several building blocks already in place. Some of the latest entrepreneurial internationalization research also provides a basis for more in-depth analysis of the internationality of the opportunities. The point is to ask how the opportunity actually spans multiple national contexts and how that influences the nature and development of an IBO. Asking that question should direct our attention to the situational and dynamic character of IBOs.

\section{References}

Acedo, F. and Casillas, J. (2005). Current paradigms in the international management field: an author co-citation analysis. International Business Review, 14, pp. 619-639.

Acedo, F. and Jones, M. (2007). Speed of internationalization and entrepreneurial cognition: insights and a comparison between international new ventures, exporters and domestic firms. Journal of World Business, 42, pp. 236-252.

Acs, Z., Morck, R. and Yeung, B. (2001). Entrepreneurship, globalization, and public policy. 
Journal of International Management, 7, pp. 235-251.

Alvarez, S. and Barney, J. (2007). Discovery and creation: alternative theories of entrepreneurial action. Strategic Entrepreneurship Journal, 1, pp. 11-26.

Alvarez, S. and Barney, J. (2010). Entrepreneurship and epistemology: the philosophical underpinnings of the study of entrepreneurial opportunities. Academy of Management Annals, 4, pp. 557-583.

Andersen, O. (1993). On the internationalization process of firms: a critical analysis. Journal of International Business Studies, 24, pp. 209-231

Anokhin, S., Wincent, J. and Autio, E. (2011). Operationalizing opportunities in entrepreneurship research: use of data envelopment analysis. Small Business Economics, 2011, 37, pp. 39-57.

Ardichvili, A., Cardozo, R. and Ray, S. (2003). A theory of entrepreneurial opportunity identification and development. Journal of Business Venturing, 18, pp. 105-123.

Aspelund, A., Madsen, T.K. and Moen, Ø. (2007). A review of the foundation, international marketing strategies and performance of international new ventures. European Journal of Marketing, 41, pp. 1423-1448.

Autio, E. (2005). Creative tension: the significance of Ben Oviatt's and Patricia McDougall's article 'toward a theory of international new ventures'. Journal of International Business Studies, 36, pp. 9-19.

Autio, E., Sapienza, H. and Almeida, J. (2000). Effects of age at entry, knowledge intensity, and imitability on international growth. Academy of Management Journal, 43, pp. 909-924.

Baker, T., Gedajlovic, E. and Lubatkin, M. (2005). A framework for comparing entrepreneurship processes across nations. Journal of International Business Studies, 36, pp. 492-504.

Bhaskar, R., 2008. A Realist Theory of Science, third ed. London: Verso.

Bilkey, W. and Tesar, G. (1977). The export behavior of smaller-sized Wisconsin manufacturing firms. Journal of International Business Studies, 8, pp. 93-98.

Birkinshaw, J. (1997). Entrepreneurship in multinational corporations: the characteristics of subsidiary initiatives. Strategic Management Journal, 18, pp. 207-229.

Boojihawon, D., Dimitratos, P. and Young, S. (2007). Characteristics and influences of multinational subsidiary entrepreneurial culture: the case of the advertising sector. International Business Review, 16, pp. 549-572.

Buttriss, G. and Wilkinson, I. (2006). Using narrative sequence methods to advance international entrepreneurship theory. Journal of International Entrepreneurship, 4, pp. 157-174.

Casson, M., Dark, K. and Gulamhussen, M.A. (2009) Extending internalisaton theory: from the multinational enterprise to the knowledge-based empire. International Business Review, 18, pp. 236-256.

Cavusgil, S.T. (1980). On the internationalization process of firms. European Research, 8, pp. 273-281.

Chandra, Y. and Coviello, N. (2010). Broadening the concept of international entrepreneurship: 'consumers as international entrepreneurs'. Journal of World Business, 45, pp. 228-236.

Chandra, Y., Styles, C. and Wilkinson, I. (2009). The recognition of first time international entrepreneurial opportunities. International Marketing Review, 26, pp. 30-61.

Chiasson, M. and Saunders, C. (2005). Reconciling diverse approaches to opportunity research using the structuration theory. Journal of Business Venturing, 20, pp. 747767. 
Chiles, T., Bluedorn, A. and Gupta, V. (2007). Beyond creative destruction and entrepreneurial discovery: a radical Austrian approach to entrepreneurship. Organization Studies, 28, pp. 467-493.

Cohen, B. and Winn, M. (2007). Market imperfections, opportunity and sustainable entrepreneurship. Journal of Business Venturing, 22, pp. 29-49.

Cornelissen, J. and Clarke, J. (2010). Imagining and rationalizing opportunities: inductive reasoning and the creation and justification of new ventures. Academy of Management Review, 35, pp. 539-557.

Coviello, N. (2006). The network dynamics of international new ventures. Journal of International Business Studies, 37, pp. 713-731.

Coviello, N. and Jones, M. (2004). Methodological issues in international entrepreneurship research. Journal of Business Venturing, 19, pp. 485-508.

Coviello, N. and Munro, H. (1995). Growing the entrepreneurial firm: networking for international market development. European Journal of Marketing, 29, pp. 49-61.

Crick, D. and Jones, M. (2000). Small high-technology firms and international hightechnology markets. Journal of International Marketing, 8, pp. 63-85.

Crick, D. and Spence, M. (2005). The internationalization of 'high performing' UK high-tech SMEs: a study of planned and unplanned strategies. International Business Review, 14, pp. 167-185.

Crick, D. (2007). UK SMEs' motives for internationalizing: differences between firms employing particular overseas market servicing strategies. Journal of International Entrepreneurship, 5, pp. 11-23.

Crick, D., Chaundry, S. and Batstone, S. (2001). An investigation into the overseas expansion of small Asian-owned U.K. firms. Small Business Economics, 16, pp. 75-94.

Dana L.-P. (1995). Entrepreneurship in a remote sub-arctic community. Entrepreneurship Theory and Practice, 20, pp. 57-72.

Dana L.-P., Hamilton, R. and Wick, K. (2009). Deciding to export: an exploratory study of Singaporean entrepreneurs. Journal of International Entrepreneurship, 7, pp. 79-87.

Davidsson, P. (2004). Researching Entrepreneurship. International Studies in Entrepreneurship, 5. New York: Springer.

Davidsson, P., Hunter, E. and Klofsten, M. (2006). Institutional forces: the invisible hand that shapes venture ideas? International Small Business Journal, 24, pp. 115-131.

De Clercq, D., Danis, W. and Dakhli, M. (2010). The moderating effect of institutional context on the relationship between associational activity and new business activity in emerging economies. International Business Review, 19, pp. 85-101.

De Clercq, D., Sapienza, H. and Crijns, H. (2005). The internationalization of small and medium-sized firms. Small Business Economics, 24, pp. 409-411.

De Clercq, D. and Voronov, M. (2009). Toward a practice perspective of entrepreneurship: entrepreneurial legitimacy as habitus. International Small Business Journal, 27, pp. 395-419.

Di Gregorio, D. (2005). Re-thinking country risk: insights from entrepreneurship theory. International Business Review, 14, pp. 209-226.

Di Gregorio, D., Musteen, M. and Thomas, D. (2008). International new ventures: the crossborder nexus of individuals and opportunities. Journal of World Business, 43, pp. 186-196.

Dimitratos, P., Plakoyiannaki, E., Pitsoulaki, A. and Tüselmann, H.J. (2010). The global smaller firm in international entrepreneurship. International Business Review, 19, pp. 589-606.

Eckhardt, J. and Shane, S. (2003). Opportunities and entrepreneurship. Journal of 
Management, 29, pp. 333-349.

Edelman, L. and Yli-Renko, H. (2010). The impact of environment and entrepreneurial perceptions on venture-creation efforts: bridging the discovery and creation views of entrepreneurship. Entrepreneurship Theory and Practice, 34, pp. 833-856.

Evangelista, F. (2005). Qualitative insights into the international new venture creation process. Journal of International Entrepreneurship, 3, pp. 179-198.

Feldman, M. and Orlikowski, W (2011). Theorizing practice and practicing theory. Organization Science, 22, pp. 1240-1253.

Fletcher, D. (2004). International entrepreneurship and the small firms. Entrepreneurship and Regional Development, 16, pp. 289-305.

Fletcher, D. (2007). 'Toy Story': the narrative world of entrepreneurship and the creation of interpretive communities Journal of Business Venturing, 22, pp. 649-672.

Freeman, S., Hutchings, K., Lazaris, M. and Zyngier, S. (2010). A model of rapid knowledge development: the smaller born global firm. International Business Review, 19, pp. 70 84.

Gartner, W. (1988). "Who is an entrepreneur?" is the wrong question. American Journal of Small Business, Spring, pp. 11-32.

Gartner, W. (2010). A new path to the waterfall: a narrative on a use of entrepreneurial narrative. International Small Business Journal, 28, pp. 6-19.

Godley, A. and Casson, M. (2007). Revisiting the emergence of the modern business enterprise: entrepreneurship and the Singer global distribution system. Journal of Management Studies, 44, pp. 1064-1077.

Greenhalgh, T., Robert, G., Macfarlane, F. and Kyriakidou, O. (2004). Diffusion of innovations in service organizations: systematic review and recommendations. Milbank Quarterly, 82, pp. 581-629.

Grégoire, D., Corbett, A. and McMullen, J. (2011). The cognitive perspective in entrepreneurship: an agenda for future research. Journal of Management Studies, $\mathbf{4 8 ,}$ pp. 1443-1477.

Han, M. (2006). Developing social capital to achieve superior internationalization: a conceptual model. Journal of International Entrepreneurship, 4, pp. 99-112.

Hayek, F. (1948). Individualism and Economic Order, first ed. Chicago: University of Chicago Press.

Hohenthal, J., Johanson, J. and Johanson, M. (2003). Market discovery and the international expansion of the firm. International Business Review, 12, pp. 659-672.

Ibeh, K. (2003). Toward a contingency framework of export entrepreneurship: conceptualisations and empirical evidence. Small Business Economics, 20, pp. 49-68.

Ireland, R.D., Hitt, M. and Sirmon, D. (2003). A model of strategic entrepreneurship: the construct and its dimensions. Journal of Management, 29, pp. 963-989.

Isenberg, D. (2008). The global entrepreneur: a new breed of entrepreneur is thinking across borders - from day one. Harvard Business Review, 86, pp. 107-111.

Jantunen, A., Nummela, N., Puumalainen, K. and Saarenketo, S. (2008). Strategic orientations of born globals - do they really matter? Journal of World Business, 43, pp. $158-170$.

Johanson, J. and Mattsson, L.-G. (1988). Internationalisation in industrial systems - a network approach. In Hood, N. and Vahlne, J.-E. (eds), Strategies in Global Competition. London: Croom Helm, London, pp. 468-486.

Johanson, J. and Vahlne, J.-E. (1977). The internationalization process of the firm - a model of knowledge development and increasing foreign market commitments. Journal of International Business Studies, 8, pp. 23-32. 
Johanson, J. and Vahlne, J.-E. (1990). The mechanism of internationalisation. International Marketing Review, 7, pp. 11-24.

Johanson, J. and Vahlne, J.-E. (2003). Business relationship learning and commitment in the internationalization process. Journal of International Entrepreneurship, 1, pp. 83101.

Johanson, J. and Vahlne, J.-E. (2006). Commitment and opportunity development in the internationalization process: a note on the Uppsala internationalization process model. Management International Review, 46, pp. 165-178.

Johanson, J. and Vahlne, J.-E. (2009). The Uppsala internationalization model revisited from liability of foreigness to liability of outsidership. Journal of International Business Studies, 40, pp. 1411-1431.

Jolly, V., Alahuhta, M. and Jeannet, J.-P. (1992). Challenging the incumbents: how high technology start-ups compete globally. Journal of Strategic Change, 1, pp. 71-82.

Jones, M. and Coviello, N. (2005). Internationalisation: conceptualising an entrepreneurial process of behaviour in time. Journal of International Business Studies, 36, pp. 284303.

Jones, M. V., Coviello, N. and Tang, Y.K. (2011). International entrepreneurship research (1989-2009): a domain ontology and thematic analysis. Journal of Business Venturing, 26, pp. 632-659.

Karagozoglu, N. and Lindell, M. (1998). Internationalization of small and medium-sized technology-based firms: an exploratory study. Journal of Small Business Management, 36, pp. 44-59.

Karra, N., Phillips, N. and Tracey, P. (2008). Building the born global firm: developing entrepreneurial capabilities for international new venture success. Longe Range Planning, 41, pp. 440-458.

Katz, J. and Boal, K. (2002). Entrepreneurship journal rankings. Available at: http://www.marketingtechie.com/ articles/mtart20020307.pdf (accessed 31 August 2010).

Kirzner, I. (1973). Competition and Entrepreneurship, first ed. Chicago: University of Chicago Press.

Kirzner, I. (1997=. Entrepreneurial discovery and the competitive market process: an Austrian approach. Journal of Economic Literature, 35, pp. 60-85.

Kiss, A. and Danis, W. (2008). Country institutional context, social networks, and new venture internationalization speed. European Management Journal, 26, pp. 388-399.

Kitchenham, B. (2004). Procedures for Undertaking Systematic Reviews. Joint Technical Report, Keele University (TR/SE-0401) and National ICT Australia, Itd (0400011T.1).

Knight, G. and Cavusgil, S.T. (2004). Innovation, organizational capabilities, and the bornglobal firm. Journal of International Business Studies, 35, pp. 124-141.

Kocak, A. and Abimbola, T. (2009). The effects of entrepreneurial marketing on born global performance. International Marketing Review, 26, pp. 439-452.

Kontinen, T. and Ojala, A. (2011). Network ties in the international opportunity recognition of family SMEs. International Business Review, 20, pp. 440-453.

Kropp, F., Lindsay, N. and Shoham, A. (2006). Entrepreneurial, market, and learning orientations and international entrepreneurial business venture performance in South African firms. International Marketing Review, 23, pp. 504-523.

Kuemmerle, W. (2002). Home base and knowledge management in international ventures. Journal of Business Venturing, 17, pp. 99-122.

Lee, S., Williams, C. and (2007). Dispersed entrepreneurship within multinational 
corporations: a community perspective. Journal of World Business, 42, pp. 505-519.

Liu, X., Xiao, W. and Huang, X. (2008). Bounded entrepreneurship and internationalization of indigenous Chinese private-owned firms. International Business Review, 17, pp. 488-508.

Lorentz, H. and Ghauri, P. (2008). Demand supply network opportunity development processes in emerging markets: positioning for strategy realization in Russia. Industrial Marketing Management, 39, pp. 240-251.

Lumpkin, G. and Dess, G. (1996). Clarifying the entrepreneurial orientation and linking it to performance. Academy of Management Review, 21, pp. 135-172.

Madsen, T.K. and Servais, P. (1997). The internationalisation of born globals: an evolutionary process? International Business Review, 6, pp. 561-583.

Mahnke, V., Venzin, M. and Zahra, S. (2007). Governing entrepreneurial opportunity recognition in MNEs: aligning interest and cognition under uncertainty. Journal of Management Studies, 44, pp. 1278-1298.

Mainela, T. and Puhakka, V. (2009). Organising new business in turbulent context. Opportunity-creation and effectuation behaviours for IJV in transition markets. Journal of International Entrepreneurship, 7, pp. 111-134.

Mathews, J. and Zander, I. (2007). The international entrepreneurial dynamics of accelerated internationalisation. Journal of International Business Studies, 38, pp. 387-403.

McDougall, P. (1989). International vs. domestic entrepreneurship: new venture strategic behavior and industry structure. Journal of Business Venturing, 4, pp. 387-400.

McDougall, P. and Oviatt, B. (2000). International entrepreneurship: the intersection of two research paths. Academy of Management Journal, 43, pp. 902-908.

McDougall, P., Shane, S. and Oviatt, B. (1994). Explaining the formation of international new ventures: the limits of theories from international business research. Journal of Business Venturing, 9, pp. 469-487.

McGaughey, S. (2007). Hidden ties in international new venturing: the case of portfolio entrepreneurship. Journal of World Business, 42, pp. 307-321.

McMullen, J. and Shepherd, D. (2006). Entrepreneurial actions and the role of uncertainty in the theory of the entrepreneur. Academy of Management Review, 31, pp. 132-152.

Merton, R.K. (1967). On Theoretical Sociology. New York: Free Press.

Mitchell, J.R. and Shepherd, D. (2010). To thine own self be true: images of self, images of opportunity, and entrepreneurial action. Journal of Business Venturing, 25, pp. 138154.

Mittelstaedt, J.D., Ward, W.A. and Nowlin, E. (2006). Location, industrial concentration and the propensity of small US firms to export. Entrepreneurship in the international marketplace. International Marketing Review, 23, pp. 486-503.

Moen, Ø. and Servais, P. (2002). Born global or gradual global? Examining the export behavior of small and medium-sized enterprises. Journal of International Marketing, 10, pp. 49-72.

Murphy, P.J. (2011). A $2 \times 2$ conceptual foundation for entrepreneurial discovery theory. Entrepreneurship Theory and Practice, 35, pp. 359-374.

Muzychenko, O. (2008). Cross-cultural entrepreneurial competence in identifying international business opportunities. European Management Journal, 26, pp. 366377.

Nasra, R. and Dacin, T. (2010). Institutional arrangements and international entrepreneurship: the state as institutional entrepreneur. Entrepreneurship Theory and Practice, 34, pp. 583-609.

Newey, L. and Zahra, S. (2009). The evolving firm: how dynamic and operating capabilities 
interact to enable entrepreneurship. British Journal of Management, 20, pp. 81-100.

Nordman, E. and Melén, S. (2008). The impact of different kinds of knowledge for the internationalization process of born globals in the biotech business. Journal World Business, 43, pp. 171-185.

Oviatt, B. and McDougall, P. (1994). Toward a theory of international new ventures. Journal of International Business Studies, 25, pp. 45-64.

Oviatt, B. and McDougall, P. (2005). Defining international entrepreneurship and modeling the speed of internationalization. Entrepreneurship Theory and Practice, 29, pp. 537554.

Ozgen, E. and Baron, R. (2007). Social sources of information in opportunity recognition: effects of mentors, industry networks, and professional forums. Journal of Business Venturing, 22, pp. 174-192.

Park, S. and Bae, Z.-B. (2004). New venture strategies in a developing country: identifying a typology and examining growth patterns through case studies. Journal of Business Venturing, 19, pp. 81-105.

Pentland, B. (1999). Building process theory with narrative: from description to explanation. Academy of Management Review, 24, pp. 711-724.

Perks, K. and Hughes, M. (2008). Entrepreneurial decision-making in internationalization: propositions from mid-size firms. International Business Review, 17, pp. 310-330.

Pike, K. (1967). Language in Relation to a Unified Theory of Structure of Human Behavior (2nd ed.), Hague: Mouton.

Pinder, C. and Moore, L. (1980). Middle Range Theory and the Study of Organizations. Dordrecht: Kluwer.

Pla-Barber, J. and Escrobá-Esteve, A. (2006). Accelerated internationalisation: evidence from a late investor country. International Marketing Review, 23, pp. 255-278.

Prashantham, S. (2008). New venture internationalization as strategic renewal. European Management Journal, 26, pp. 378-387.

Preece, S., Miles, G. and Baetz, M. (1998). Explaining the international intensity and global diversity of early stage technology based firms. Journal of Business Venturing, 14, pp. 259-281.

Rasmussen, E., Madsen, T. and Evangelista, F. (2001) The founding of the born global company in Denmark and Australia: sensemaking and networking. Asia Pacific Journal of Marketing and Logistics, 13, pp. 75-107.

Rennie, M. (1993). Born global. McKinsey Quarterly, 4, pp. 45-52.

Rindova, V., Barry, D. and Ketchen, D. (2009). Entrepreneuring as emancipation. Academy of Management Review, 34, pp. 477-491.

Sandberg, J. and Tsoukas, H. (2011). Grasping the logic of practice: theorizing through practical rationality. Academy of Management Review, 36, pp. 338-360.

Santos, F. and Eisenhardt, K. (2009). Constructing markets and shaping boundaries: entrepreneurial power in nascent fields. Academy of Management Journal, 52, pp. 643-671.

Sapienza, H., Autio, E., George, G. and Zahra, S. (2006). A capabilities perspective on the effects of early internationalization on firm survival and growth. Academy of Management Review, 31, pp. 914-933.

Sarasvathy, S. (2001). Causation and effectuation: toward a theoretical shift from economic inevitability to entrepreneurial contingency. Academy of Management Review, 26, pp. 243-288.

Sarasvathy, S., Dew, N., Velamuri, S. and Venkataraman, S. (2003). Three views of entrepreneurial opportunity. In Acs, Z. and Audretsch, D. (eds), Handbook of 
Entrepreneurship Research: An Interdisciplinary Survey and Introduction. New York: Springer, pp. 141-160.

Sasi, V. and Arenius, P. (2008). International new ventures and social networks: advantage or liability? European Management Journal, 26, pp. 400-411.

Schumpeter, J. (1934). The Theory of Economic Development, first ed. Cambridge, MA: Harvard University Press

Schweizer, R., Vahlne, J-E. and Johanson, J. (2010). Internationalization as an entrepreneurial process. Journal of International Entrepreneurship, 8, pp. 343-370.

Sequeira, J., Carr, J. and Rasheed, A. (2009). Transnational entrepreneurship: determinants of firm type and owner attributions of success. Entrepreneurship Theory and Practice, 33, pp. 1023-1044.

Shane, S. (2000). Prior knowledge and the discovery of entrepreneurial opportunities. Organization Science, 11, pp. 448-469.

Shane, S. (2003). A General Theory of Entrepreneurship: The individual Opportunity Nexus. Cheltenham: Edward Elgar.

Shane, S. and Venkataraman, S. (2000). The promise of entrepreneurship as a field of research. Academy of Management Review, 25, pp. 217-226.

Shaw, V. and Darroch, J. (2004). Barriers to internationalisation: a study of entrepreneurial new ventures in New Zealand. Journal of International Entrepreneurship, 2, pp. 327343.

Shepherd, D. and Sutcliffe, K. (2011). Inductive top-down theorizing: a source of new theories of organization. Academy of Management Review, 36, pp. 361-380.

Short, J., Ketchen, D., Shook, C. and Ireland, R.D. (2010). The concept of "opportunity" in entrepreneurship research: past accomplishments and future challenges. Journal of Management, 36, pp. 40-65.

Spence, M. and Crick, D. (2006). A comparative investigation into the internationalisation of Canadian and UK high-tech SMEs. International Marketing Review, 23, pp. 524-548.

Stevenson, H. and Gumpert, D. (1985). The heart of entrepreneurship. Harvard Business Review, 63, pp. 85-94.

Stevenson, H. and Jarillo, C. (1986). Preserving entrepreneurship as companies grow. Journal of Business Strategy, 6, pp. 10-23.

Stevenson, H. and Jarillo, C. (1990). A paradigm of entrepreneurship: entrepreneurial management. Strategic Management Journal, 11, pp. 17-27.

Steyaert, C. (2007). 'Entrepreneuring' as a conceptual attractor? A review of process theories in 20 years of entrepreneurship studies. Entrepreneurship and Regional Development, 19, pp. 453-477.

Strauss, A. and Corbin, J. (1990). Basics of Qualitative Research: Grounded Theory Procedures and Techniques. London: Sage.

Styles, C. and Genua, T. (2008). The rapid internationalization of high technology firms created through the commercialization of academic research. Journal of World Business, 43, pp. 146-157.

Sullivan Mort, G. and Weerawardena, J. (2006). Network capability and international entrepreneurship. How network function in Australian born global firms. International Marketing Review, 23, pp. 549-572.

Tsoukas, H. (1989). The validity of idiographic research explanations. Academy of Management Review, 14, pp. 551-561.

Vaghely, I. and Julien, P.-A. (2010). Are opportunities recognized or constructed? An information perspective on entrepreneurial opportunity identification. Journal of Business Venturing, 25, pp. 73-86. 
Van de Ven, A. and Engleman, R. (2004). Event- and outcome-driven explanations of entrepreneurship. Journal of Business Venturing, 19, pp. 343-358.

Wakkee, I. (2006). Mapping network development of international new ventures with the use of company e-mails. Journal of International Entrepreneurship, 4, pp. 191-208.

Webb, J., Kistruck, G., Ireland, R.D. and Ketchen, D. (2010). The Entrepreneurship process in base of the pyramid markets: the case of multinational enterprise/nongovernment organization alliances. Entrepreneurship Theory and Practice, 34, pp. 555-581.

Welch, L. and Wiedersheim-Paul, F. (1980). Initial exports - a marketing failure? Journal of Management Studies, 17, pp. 333-344.

Wiedersheim-Paul, F., Olson, H. and Welch, L. (1978). Pre-export activity: the first step in internationalization. Journal of International Business Studies, 9, pp. 47-58.

Williams, C. and Lee, S. (2009). International management, political arena and dispersed entrepreneurship in the MNC. Journal of World Business, 44, pp. 287-299.

Wood, M. and W. McKinley (2010). The production of entrepreneurial opportunity: a constructivist perspective. Strategic Entrepreneurship Journal, 4, pp. 66-84.

Zahra, S. (2005). A theory of international new ventures: a decade of research. Journal of International Business Studies, 36, pp. 20-28.

Zahra, S. (2008). The virtuous cycle of discovery and creation of entrepreneurial opportunities. Strategic Entrepreneurship Journal, 2, pp. 243-257.

Zahra, S., Hayton, J., Marcel, J. and O’Neill, H. (2001). Fostering entrepreneurship during international expansion: managing key challenges. European Management Journal, 19, pp. 359-369.

Zahra, S. and Hayton, J. (2008). The effect of international venturing on the firm performance: the moderating influence of absorptive capacity. Journal of Business Venturing, 23, pp. 195-220.

Zahra, S., Jennings, D. and Kuratko, D. (1999). The antecedents and consequences of firmlevel entrepreneurship: the state of the field. Entrepreneurship Theory and Practice, 24, pp. 45-63.

Zahra, S., Korri, J.S. and Yu, J. (2005). Cognition and international entrepreneurship: implications for research on international opportunity recognition and exploitation. International Business Review, 14, pp. 129-146.

Zander, I. (2004). The microfoundations of cluster stickness - walking in the shoes of the entrepreneur. Journal of International Management, 10, pp. 151-175.

Zhou, L. (2007). The effects of entrepreneurial proclivity and foreign market knowledge on early internationalization. Journal of World Business, 42, pp. 281-293.

Zhou, L., Barnes, B. and Luo, Y. (2010). Entrepreneurial proclivity, capability upgrading and performance advantage of newness among international new ventures. Journal of International Business Studies, 41, pp. 882-905. 
Table 1. Conceptualizations of opportunities

\begin{tabular}{ll}
\hline Conceptualization & Determining characteristics \\
\hline Innovation opportunity & Is driven by motivation to entrepreneurial action \\
& Starts with economic invention by entrepreneur \\
& Manifests as novel resource combination \\
& Creates disequilibrium in markets \\
Arbitrage opportunity & Is driven by entrepreneurs alert to market information \\
& Starts with noting of demand-supply inefficiencies \\
& Manifests as new markets \\
& Creates equilibrium in markets \\
& Produces a complex entity \\
Opportunity discovery & Involves active search behavior \\
& Exploits rational decision making under risky conditions \\
& Constructs a flexible activity \\
Opportunity creation & Enactment in everyday entrepreneurial practice \\
& Develops through social interaction under true uncertainty \\
\hline
\end{tabular}


Table 2. Protocol for identifying relevant entrepreneurial internationalization literature

Criteria
(1) Publication in a peer-reviewed academic journal

(2) Publication between 1989 and 2010 (including articles in press in 2010)

(3) Publication as a full-length journal article or research note

(4) Publication in the field of IE

(5) Keywords 'internationalization/ international/born global/export' AND

'entrepreneurship/ entrepreneurial/ entrepreneur' used in the title, abstract or keywords of the article

(6) Incorporating the concept of opportunity

\section{Rationales}

We chose the business and management journals with an ISIimpact factor $\geq 1.000$ in the 2009 ranking ( 83 journals) to secure quality and accessibility.

We cross-checked the listing with the most influential international management and entrepreneurship journals and added 2 journals.

We added topic-specialized Journal of International Entrepreneurship and European Management Journal as it has special issue on the topic and has continued to publish IE articles.

We chose the starting point to correspond with publication of McDougall (1989) that is seminal in combining entrepreneurship and international business in study of new ventures.

We excluded general level reviews, editorials and commentaries providing overviews of the field.

We conducted hand search in the selected journals with intentionally wide scope so that all possible IE articles were chosen.

We then searched the journals through keywords 'international entrepreneurship', 'entrepreneurship', 'small business', 'opportunity', 'international' and 'internationalization' to ensure that the selection is not biased because of our interpretation but rests on how the author's position their works.

We reviewed citations to Oviatt and McDougall (1994) as a leading study in the field and examined references of the previous IE reviews with cross-disciplinary emphasis (Coviello and Jones, 2004; Jones at al., 2011) to identify missed relevant works.

IE was defined as a cross-disciplinary research field that combines international business and entrepreneurship.

We aimed to secure explicit use of both root theories by requirement of relating to both theories in titles, abstracts or keywords.

We then ensured that the articles explicitly incorporated concepts from both theories through review of the theoretical sections.

The occurrences of the word 'opportunity' were recorded and the contexts of the concept use were analyzed.

We chose articles that reported opportunity as a concept in the research objective or theoretical framework, as a variable in a questionnaire or a topic in an interview guide or in conceptualizing and modeling the research results.

The articles that combined international business and entrepreneurship theories but used opportunity as a common expression or in single sentences were excluded. 
Table 3. Identified IE articles published on the period 1989-2010

\begin{tabular}{|c|c|c|c|c|}
\hline Journal & Reviews/editorials & $\begin{array}{l}\text { IE non } \\
\text { IBO }\end{array}$ & IBO in IE & Total \\
\hline Academy of Management Journal & 1 & 2 & 1 & 4 \\
\hline Academy of Management Review & & & 1 & 1 \\
\hline Entrepreneurship and Regional Development & & 3 & 1 & 4 \\
\hline Entrepreneurship Theory and Practice & 3 & 7 & 4 & 14 \\
\hline European Management Journal & 1 & 4 & 4 & 9 \\
\hline Harvard Business Review & & & 1 & 1 \\
\hline Industrial Marketing Management & & & 1 & 1 \\
\hline International Business Review & 3 & 10 & 11 & 24 \\
\hline International Marketing Review & 2 & & 7 & 9 \\
\hline International Small Business Journal & & 2 & & 2 \\
\hline Journal of Business Venturing & 1 & 10 & 6 & 17 \\
\hline Journal of International Business Studies & 2 & 8 & 5 & 15 \\
\hline Journal of International Entrepreneurship & 4 & 6 & 7 & 17 \\
\hline Journal of International Management & 1 & 1 & 2 & 4 \\
\hline Journal of International Marketing & 1 & 4 & 1 & 6 \\
\hline Journal of Management & 1 & & & 1 \\
\hline Journal of Management Studies & & 1 & 1 & 2 \\
\hline Journal of Small Business Management & & & 1 & 1 \\
\hline Journal of World Business & 1 & 6 & 10 & 17 \\
\hline Long Range Planning & & & 1 & 1 \\
\hline Management International Review & & & 1 & 1 \\
\hline Organization Studies & & 1 & & 1 \\
\hline Small Business Economics & 3 & 6 & 3 & 12 \\
\hline \multirow[t]{2}{*}{ Strategic Management Journal } & 1 & 2 & 1 & 4 \\
\hline & 25 & 73 & 70 & 168 \\
\hline
\end{tabular}


Table 4. Analysis procedure

\begin{tabular}{|c|c|c|}
\hline Phase & Content & Ilustration \\
\hline \multirow[t]{6}{*}{ Mapping } & Open coding & \\
\hline & Emic, data-driven codes & $\begin{array}{l}\text { Studying the articles from inside; categories } \\
\text { that emerged from the articles }\end{array}$ \\
\hline & Etic, theory-led codes & $\begin{array}{l}\text { Studying the articles from outside; } \\
\text { categorizing the articles by using codes } \\
\text { derived from the previous research }\end{array}$ \\
\hline & Axial coding & $\begin{array}{l}\text { Studying the articles by relating codes to each } \\
\text { other in order to find the unifying core } \\
\text { concepts representing the central phenomena } \\
\text { of research }\end{array}$ \\
\hline & Selective coding & \\
\hline & & $\begin{array}{l}\text { Studying the articles from the perspective of } \\
\text { the unifying, focal core code in order to find } \\
\text { the underlining research streams }\end{array}$ \\
\hline \multirow[t]{3}{*}{ Appraisal } & Evaluation & $\begin{array}{l}\text { Evaluation of the articles in respect of } \\
\text { validity and relevance to the study }\end{array}$ \\
\hline & Extraction and collation & $\begin{array}{l}\text { Collecting and ordering the key results of the } \\
\text { articles }\end{array}$ \\
\hline & Grouping & Clustering together equivalent research \\
\hline \multirow[t]{2}{*}{ Synthesis } & Identification of research streams & $\begin{array}{l}\text { Defining research streams by identification of } \\
\text { common key elements, concepts and results } \\
\text { in each research stream }\end{array}$ \\
\hline & Narrative of each research stream on IBOs & $\begin{array}{l}\text { Narrative account of the contribution by each } \\
\text { distinct research stream on IBOs }\end{array}$ \\
\hline
\end{tabular}


Table 5. The reviewed studies on IBOs in entrepreneurial internationalization

\begin{tabular}{|c|c|c|}
\hline Study & Method & Research focus \\
\hline \multicolumn{3}{|c|}{ I IBO based INVs and MNC renewal } \\
\hline McDougall et al. 1994 & Case study & Factors explaining formation of INVs \\
\hline Birkinshaw 1997 & $\begin{array}{l}\text { Interviews, } \\
\text { questionnaire }\end{array}$ & $\begin{array}{l}\text { Facilitators, process and outcomes of subsidiary initiatives in } \\
\text { MNCs }\end{array}$ \\
\hline Autio et al. 2000 & Survey & $\begin{array}{l}\text { Effect of firm age at first international sales, knowledge } \\
\text { intensity and imitability on growth }\end{array}$ \\
\hline Kuemmerle 2002 & Case study & INV evolution and knowledge management \\
\hline Knight and Cavusgil 2004 & Interviews, survey & $\begin{array}{l}\text { Role of innovative culture and capabilities in early } \\
\text { internationalization and performance of BGs }\end{array}$ \\
\hline Park and Bae 2004 & Case study & New venture strategies and growth patterns \\
\hline Evangelista 2005 & Case study & Formative period of INVs \\
\hline Kropp et al. 2006 & Survey & $\begin{array}{l}\text { Entrepreneurial, market and learning orientations and INV } \\
\text { performance }\end{array}$ \\
\hline Boojihavon et al. 2007 & Case study & Entrepreneurial culture of MNC subsidiaries \\
\hline Karra et al. 2008 & Case study & Capabilities for INV success \\
\hline Zahra and Hayton 2008 & Survey & International venturing activities and performance \\
\hline Sequeira et al. 2009 & Survey & $\begin{array}{l}\text { Attitudes, perceptions and embeddedness in the host country } \\
\text { in transnational entrepreneurship }\end{array}$ \\
\hline De Clercq et al. 2010 & $\begin{array}{l}\text { Secondary data, } \\
\text { quantitative }\end{array}$ & $\begin{array}{l}\text { Social networks and institutional burden in new business } \\
\text { activity }\end{array}$ \\
\hline $\begin{array}{l}\text { Oviatt and McDougall } \\
1994\end{array}$ & Conceptual & Necessary elements for the existence of INVs \\
\hline Acs et al. 2001 & Conceptual & How to take SME innovations to international markets \\
\hline Zahra et al. 2001 & Conceptual & Challenges in promoting entrepreneurship in MNCs \\
\hline Zander 2004 & Conceptual & Cognition in spatial and sectoral concentration of firms \\
\hline Di Gregorio 2005 & Conceptual & Country risk as an opportunity to profit from uncertainty \\
\hline Sapienza et al. 2006 & Conceptual & Internationalization and survival and growth of firms \\
\hline Lee and Williams 2007 & Conceptual & Role of entrepreneurial communities in MNCs \\
\hline Mahnke et al. 2007 & Conceptual & Opportunity identification and exploitation in MNCs \\
\hline $\begin{array}{l}\text { Matthews and Zander } \\
2007\end{array}$ & Conceptual & Entrepreneurial dynamics of accelerated internationalization \\
\hline Di Gregorio et al. 2008 & Conceptual & $\begin{array}{l}\text { Opportunity discovery, evaluation and exploitation in INVs } \\
\text { and their consequences on national economies }\end{array}$ \\
\hline Isenberg 2008 & Conceptual & Challenges faced by BGs and the skills to tackle them \\
\hline Muzychenko 2008 & Conceptual & Multicultural competencies and IBO identification \\
\hline Williams and Lee 2009 & Conceptual & Power dynamics and MNC entrepreneurship \\
\hline Webb et al. 2010 & Conceptual & $\begin{array}{l}\text { Partnerships between MNCs and NGOs to overcome the } \\
\text { institutional barriers of the entrepreneurial process }\end{array}$ \\
\hline \multicolumn{3}{|c|}{ II IBOs as a starting point for internationalization behavior } \\
\hline $\begin{array}{l}\text { Karagozoglu and Lindell } \\
1998\end{array}$ & Survey & $\begin{array}{l}\text { Motives, barriers and adaptive measures in } \\
\text { internationalization of high tech SMEs }\end{array}$ \\
\hline Preece et al. 1998 & Survey & Attitudes and structures in international activities \\
\hline Crick and Jones 2000 & Case study & Overseas expansion of technology-oriented SMEs \\
\hline Crick et al. 2001 & Interview study & Influence of ethnicity on overseas expansion \\
\hline Ibeh 2003 & Survey & External environment and export venture creation \\
\hline Shaw and Darroch 2004 & Survey & Perception of barriers to internationalization \\
\hline Crick and Spence 2005 & Case study & Internationalization strategies of high-performing SMEs \\
\hline De Clercq et al. 2005 & Survey & $\begin{array}{l}\text { Learning and perception of opportunities offered by } \\
\text { internationalization and intent of internationalization }\end{array}$ \\
\hline Mittelstaedt et al. 2006 & $\begin{array}{l}\text { Secondary data, } \\
\text { quantitative }\end{array}$ & Urbanization, industrial concentration and export propensity \\
\hline $\begin{array}{l}\text { Pla-Barber and Escriba- } \\
\text { Esteve } 2006\end{array}$ & Survey & Accelerated internationalization process \\
\hline Spence and Crick 2006 & Interview study & Internationalization strategies \\
\hline Sullivan Mort and & Case study & Features of owner-managers and networking in BGs \\
\hline
\end{tabular}


Weerawardena 2006

Acedo and Jones 2007

Crick 2007

Zhou 2007

Survey

Survey

Survey

Jantunen et al. $2008 \quad$ Survey

Liu et al. 2008

Case study

Lorenz and Ghauri 2008 Case study

Nordman and Melén 2008 Case study

Perks and Hughes 2008 Case study

Sasi and Arenius $2008 \quad$ Case study

Styles and Genua 2008

Chandra et al. 2009

Dana et al. 2009

Kocak and Abimbola

2009

Dimitratos et al. 2010

Zhou et al. 2010

Kontinen and Ojala 2011

Oviatt and McDougall 2005

Han 2006

Prashantham 2008

Freeman et al. 2010
Case study

Case study

Interview study

Case study

Case study

Survey

Case study

Conceptual

Conceptual

Conceptual

Conceptual
Cognition and speed of internationalization

Motives for internationalization and market strategies

Entrepreneurial proclivity in market learning activities and

early internationalization

Entrepreneurial, learning and international-growth

orientations and international performance

Factors influencing firm internationalization in China

Network opportunity development in emerging markets

Knowledge of founders and managers of BGs in discovery

and exploitation of market opportunities

Decision to internationalize

Social networks in rapid internationalization

Role of networks in rapid internationalization

First time international opportunity recognition

Entrepreneurial types and export triggers

Entrepreneurial marketing and performance of BGs

Entrepreneurial orientation and internationalization

Learning advantage of newness and international performance

Network ties and IBO recognition

Speed of taking entrepreneurial opportunities to international markets

Effective network ties in startup internationalization

Knowledge exploration and internationalization

Knowledge development and relationships in BGs

Iii Cross national enactment of IBOs in entrepreneurial processes

\begin{tabular}{|c|c|c|}
\hline McGaughey 2007 & Single case study & Portfolio entrepreneurship and international venturing \\
\hline $\begin{array}{l}\text { Mainela and Puhakka } \\
2009\end{array}$ & Single case study & $\begin{array}{l}\text { Opportunity-related behaviors of IJV managers in turbulent } \\
\text { markets }\end{array}$ \\
\hline Nasra and Dacin 2010 & Single case study & $\begin{array}{l}\text { Institutional context and state in IBO identification and } \\
\text { exploitation over time }\end{array}$ \\
\hline Baker et al. 2005 & Conceptual & Cross nationally embedded opportunity enactment \\
\hline Zahra et al. 2005 & Conceptual & Cognitive and context embedded enactment of IBOs \\
\hline \multicolumn{3}{|c|}{ IV Development of IBOs in internationalization processes } \\
\hline Fletcher 2004 & Case study & Enactment of IBOs in cross-border activities \\
\hline Schweizer et al. 2010 & Single case study & Network-based development of IBOs \\
\hline Hohenthal et al. 2003 & Conceptual & Market discoveries and international expansion over time \\
\hline $\begin{array}{l}\text { Johanson and Vahlne } \\
2006\end{array}$ & Conceptual & $\begin{array}{l}\text { Relationship commitment and network knowledge in } \\
\text { opportunity development }\end{array}$ \\
\hline $\begin{array}{l}\text { Johanson and Vahlne } \\
2009\end{array}$ & Conceptual & Internationalization process \\
\hline $\begin{array}{l}\text { Chandra and Coviello } \\
2010\end{array}$ & Conceptual & Consumers as international entrepreneurs \\
\hline
\end{tabular}

